\title{
REMADE IN JAPAN:
}

\section{THE CASE OF AUDREY HEPBURN}

\author{
ZEN YIPU
}

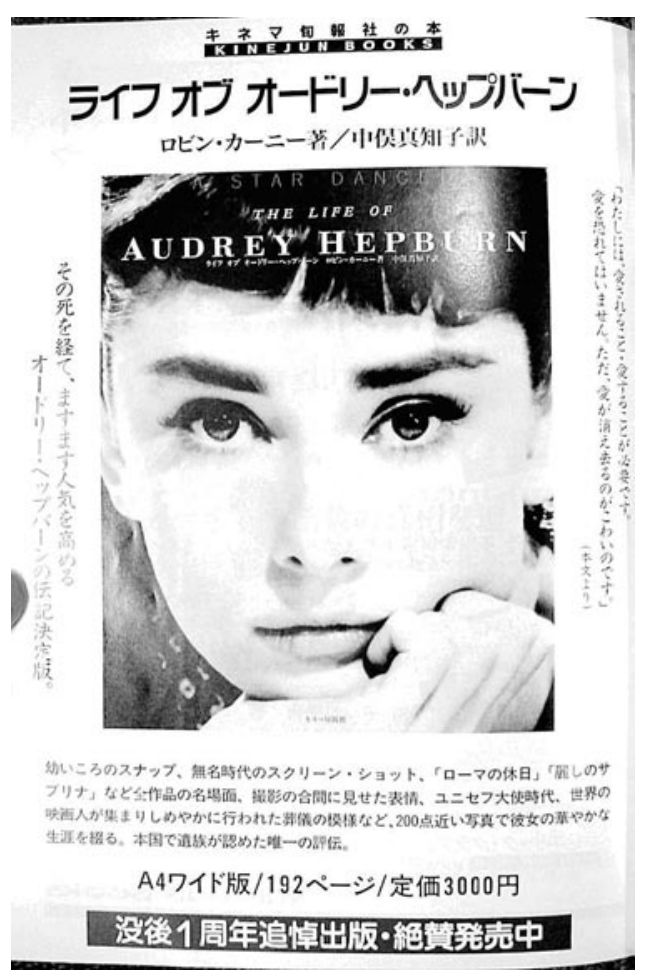

Figure 1: The face of Audrey Hepburn (AsahiGraph Extra 1999)

$\mathrm{T}$

he face of Audrey Hepburn [...] is constituted by an infinite complexity of morphological functions. As a language, Garbo's singularity was of the order of the concept, that of Audrey Hepburn is of the order of the substance. The face of Garbo is an Idea, that of Hepburn, an Event ${ }^{1}$.
Generations of Japanese female audiences who have idolised and imitated Audrey Hepburn must know precisely what Barthes meant. In 1998, five years after her death, Kirin Beverages Co. made a television commercial featuring Audrey Hepburn drinking a canned tea. A year later, Asahi Graph (AsahiGraph Extra 1999) published a special issue on Audrey Hepburn. In it, twelve Japanese idols told the readers how much they themselves idolised Audrey Hepburn. She, herself, of course does not know about her newfound career as a tea aficionada and TV commercial star in a far foreign land. Were she alive, however, she might be glad to know that this time around there would be no more death - she would remain eternally young and beautiful. She has been reproduced, digitised and saved, in bytes - a computer language enables many visual forms. Is this the same Audrey Hepburn Barthes talked about in 1957? Does it matter?

\section{'POSTMODERN' JAPANESENESS AND ITS CULTURAL PRODUCTION}

One of the most visible themes of studies on Japan since the 1980s has been the 'postmodernity' of Japanese society. Many of the phenomena in the current Japanese consumerist society seem to be rooted in its 'generic postmodernity,' 
visible in its mass media and commodification of cultures, and made more acute by the revival of semiotic and semantic interpretation of the Japanese domestication of the foreign ${ }^{3}$ and exoticisation of the native. ${ }^{4}$

This view of Japan arguably evolves around one aspect of postmodernity, the notion of cultural authenticity. 'De-differentiation', 'cultural pastiche', 'mechanical reproduction/copying' and of course the idea of 'hyperreal and of simulation', all lay significant emphasis on the idea of 'original and copy'. ${ }^{5}$ In large part, this view presumes a hierarchical order of authenticity in cultural production-in terms of a chain of 'copies' of an assumed 'original' in the cultural industry.

Benjamin's 'aura' essentially is a by-product of the 'authenticity' of art, the loss of which signifies the decay of authenticity. To Benjamin, authenticity is 'the essence of all that is transmissible from its beginning, ranging from its substantive duration to its testimony to the history which it has experienced' ${ }^{6}$ Thus, this 'aura' is the privileged experience tied to the inaccessibility of singularity and history. In his famous work 'The Work of Art in the Age of Mechanical Reproduction' Benjamin gives an example of how aura contributes to the uniqueness of art:

The uniqueness of a work of art is inseparable from its being imbedded in the fabric of tradition. This tradition itself is thoroughly alive and extremely changeable. An ancient statue of Venus, for example, stood in a different traditional context with the Greeks, who made it an object of veneration, than with the cleric of the Middle Ages, who viewed it as an ominous idol. Both of them, however, were equally confronted with its uniqueness, that is, its aura. ${ }^{7}$
What will 'aura' and 'authenticity' mean in a time when digitisation and networked communication are the norm of our media landscape? If the loss of 'aura' caused the decay of authenticity, what happens to 'aura' when authenticity no longer remains the question? As Benjamin pointed out, technology

[...] detaches the reproduced object from the domain of tradition. By making many reproductions it substitutes a plurality of copies for a unique existence. And in permitting the reproduction to meet the beholder or listener in his own particular situation, it reactivates the object reproduced. $^{8}$

Urry puts it from a different angle:

...Postmodernist culture is anti-auratic. Such forms do not proclaim their uniqueness but are mechanically and electronically reproduced. There is a denial of the separation of the aesthetic from the social and of the contention that art is of a different order from life. The value placed on the unity of the artistic work is challenged through an emphasis on pastiche, collage, allegory and so on. ... Postmodernism is anti-hierarchical, opposed to [...] vertical differentiations. ${ }^{9}$

Culture, the other attachment to the idea of authenticity, is also often seen as the result of time and adherent historical narratives. However, Appadurai sees 'culture' simply as a 'thing/object', which, 'in the contemporary world, ... is part of the capitalist civilising process' $^{10}$ In this view, 'Culture' in the form of 'code' is attached to goods and media content and can also be seen as no more than a by-product of the production and consumption process. In other words, alongside other commodities, the 
immense flow of information and knowledge produces 'culture'-one more addition to go with other non-essential 'things' for the masses. Baudrillard calls this highly mediated culture 'kitsch', and the products, 'gadgets'. He suggests that 'Kitsch is a cultural category' produced as a pseudo-event in 'current affairs' or as a pseudo-object in advertising. It can also be produced from the medium itself and its referential code becomes a 'standard package' with what is being produced and consumed. ${ }^{11}$

This essay is an analysis of 'auratic culture' in the age of digital production, an age in which the question of 'copy' and 'original' has become irrelevant. The production, in the case of Japanese Audrey Hepburn is very much cultural, and indeed is produced from the 'medium itself' and comes as a 'standard package' in the process of commodification.

I analyse the phenomenon of Audrey Hepburn's popularity among Japanese women to provide an example of how imagery and its 'aura' can be effectively commodified, and then either attached to goods or sold as a form of media content. I argue that Hepburn's lasting popularity is not just a passing fad, like many other imported foreign trends; rather, the (re)production of the Japanese Hepburn symbolises an integral part of the local economic 'tradition' of how female idols are perceived. This can be seen by analysing the functions of such idols in Japanese popular culture and comparing the rhetoric employed to describe Hepburn's image in the popular press, mainly women's magazines. I argue that the Japanese Audrey Hepburn is indeed 'authentic and original'. Although different from that of the western, European, Hollywood Audrey Hepburn, the 'culture' and 'aura' which her presence signifies in Japan, is no more exotic than that of her American counterpart. I will argue that the reproduction of Audrey Hepburn not only confuses the order of authenticity, it produces a particular kind of 'authenticity' and adopts an instant 'aura' that is only relevant to the current social milieu. Moreover, in the case of the Japanese Audrey Hepburn, the Japanese consumers re-authenticate themselves in the imagination of the reproduced virtual idol.

\section{THE MILIEU}

Audrey Hepburn, or rather, Edda van Heemstra Hepburn-Ruston, the Belgianborn Hollywood film-star from the 1950s and 60s, still remains vastly popular in Japan. She is popular not only among middle-aged women who have grown up watching her movies, and therefore might have nostalgic memories of her, but also among young women in their mid 20s who would have no such recollections of her. This latter group has learnt about her either through watching old films or through seeing her 'reincarnations' in the marketplace. There is no other western idol who enjoys the same level of popularity in Japan, a popularity which endures even today, in 2004 more than a decade after her death.

Japan is popularly believed to be racially homogeneous, culturally singular and monolingual. However, in the environs of post-war rapid economic development and the maintenance of continual economic growth, an essential feature of its fashion, culture and other trends has been 'transience'. It is commonly expected that today's pop stars will be seen as trivial passing fads by tomorrow. Like fashion, the idols of the variety shows, pop singers, models, and 
serialised TV drama actresses will be out of vogue when the trends they embody are over. Like the fast changing worlds of fashion and rapidly developing consumer electronics, the idols too are the transitory indicators of pop culture. However, since Audrey Hepburn's first popular film Roman Holiday arrived in the antiquated fashion centre of Ginza in Tokyo in 1954, her popularity has continued, flourished, and even been 'renewed' through time to the present day. With an audience who cannot racially, culturally and linguistically identify with her, one cannot help but ask a seemingly simple question: Why would a Hollywood film star of European descent from the bygone days defy the power of time and passing fashion and continue to be idolised by an anachronistic audience who are so different in race and culture?

The idolisation of film stars often can be expected where 'authenticity' of the star, real or constructed, occurs. ${ }^{12}$ By the same token, with the involvement of nostalgia and identification, the revival of popularity of old film stars might not be extraordinary. In many cases the identification in star-audience relations often takes the form of 'the desire to become', 'imitating', and 'copying' - all of which involve identification with the physical appearance. ${ }^{13}$ However, judging by the surface, Hepburn's popularity in Japan certainly does not offer the so-called cultural 'aura' for 'authenticity'. Here it is difficult to imagine a straightforward identification process, whether culturally or physically.

This might lead to a simple dismissal of Audrey Hepburn's popularity as entirely accidental and irrelevant, a conclusion which would be rather inattentive, for her popularity in Japan has now continued for some fifty years. Her magazine cover appearances rank first amongst all foreign stars in the last half a century and still remain popular amongst the readers of the popular press. ${ }^{14}$ What precisely then is it about her that generations of Japanese women admire, 'desire to become', ${ }^{15}$ and identify with? And if her popularity in Japan is comparable with that of other idols in Japan, then what provides the 'aura' for the authenticity of a Japanese Audrey Hepburn?

\section{THE IMPORTANCE OF BEING FAMILIAR-PHYSICAL RESEMBLANCE?}

Hepburn's appearance is the feature most often cited in the Japanese popular press, commanding praise notably for her dark eyes, dark hair, small physique, and even her small breast size and skinny body. In one of the very early articles about Hepburn written in 1954, it was her androgynous looks that attracted first comment:

Her eyes are clear and large, her face heart-shaped; she is capable of arousing powerful passions even though her body almost completely lacks 'volume' and is stick-thin. ${ }^{16}$

The description of her small physique as a component of her popularity has not changed some 40 years later:

[Hepburn] has black hair, black eyes and a slender physique just like the Japanese. Unlike the blonde glamour of a [Marilyn] Monroe type, her appearance has a feeling of familiarity with that of the Japanese female. ${ }^{17}$

Comments on the smallness of her features and her dark hair and eyes are still prevalent in almost all articles 
appearing in the popular press. Analysing the relationship between female spectators and their idols, Stacey has noted:

... there are numerous points of recognition of similarities between the spectator and the star. These are not based on pretending to be something one is not, but rather selecting something which establishes a link between the star and the self, based on a pre-existing part of the spectator's identity which bears a resemblance to the star. ${ }^{18}$

This insight explains, in part, one of the important reasons for Hepburn's popularity in an environment that would normally be perceived as unfamiliar. The recognition of similarities between Hepburn and her Japanese female audience might give hints as to why Hepburn has been perceived as a locally identifiable idol rather than just another imported foreign star.

\section{BECOMING HEPBURN}

The coverage accorded Audrey Hepburn in women's magazines indicates that her popularity has come from both the dramas and facts that rendered her. The dramatic ones are the screen roles she played during her career as a film star. The facts are the 'real life' stories in which Hepburn herself is the main protagonist. Typical of the former are stories of a young girl falling in love, with happy endings blessed by wealth, glamour and (of course) good taste. Sabrina (1954) is a typical example, and Roman Holiday is another. As for her real life, the most common version is that she was born in 1929 into a wealthy aristocratic family, and endured the World War II Nazi invasion of the Netherlands as a teenager. She worked hard and eventually made her break into acting in Roman Holiday in 1953, which won her world-wide acclaim and an Oscar. She continued to flourish on the silver screen until the early 1970s. In 1986, she became a Goodwill Ambassador and spokesperson for UNICEF. She is seen first and foremost as a beautiful Hollywood actress with a European aristocratic background and, at the same time, a person of kindness who helped the poor and unfortunate during her role at UNICEF. The combination of her screen appearances and real life stories is seen as a kind of ideal model for women, and indeed imitated and admired in manners widely transcendent of social classes and age groups in Japan.

A comparison between her and contemporary local Japanese pop idols would suggest similar 'qualities' said to be possessed by both current Japanese idols and Hepburn. Despite her foreign attributes, Hepburn is being idolised and emulated in similar ways as the local stars. However, although Hepburn's foreignness has not significantly distanced her audience, I suspect it remains an essential element at play in the construction of her popularity. She is more identifiable in her physical features when compared to other western stars (such as Monroe and Julia Roberts), but she remains unachievable in the identification process at the same time, precisely because of her physical differences (however small) and her Euro-American background. Thus the image of Audrey Hepburn is admired but forever inaccessible, identified but unachievable.

To bring her closer to the local audience, Hepburn is often differentiated from other famous Hollywood starsboth ones from around the same period, such as Marilyn Monroe, ${ }^{19}$ (see Figure 2: Hepburn Vs. Monroe Test), and more contemporary examples of the Ameri- 
can female star such as Julia Roberts ${ }^{20}$ (see Figure 3: Hepburn Vs. Roberts Test). These comparisons indicate that they are seen as women of fundamental differences - as might well be expected to happen if they were done in the United States. In the Japanese popular press, however, the comparisons and analysis have gone as far as comparing the different types of love life one would have ('Hepburn type or Monroe type') - with a descriptive test supplemented by graphs showing the result. Monroe and Roberts are seen primarily as representatives of American women, perhaps in similar ways as Tokyo Disneyland represented America and Venus Fort, Italy. These analyses in the popular women's magazines suggest that Hepburn is compared against the quintessential western stars, contributing to her unique status in the local media. It may also explain why, despite the fact that she is considered as identifiable and even emulateable for her Japanese fans, she is rarely

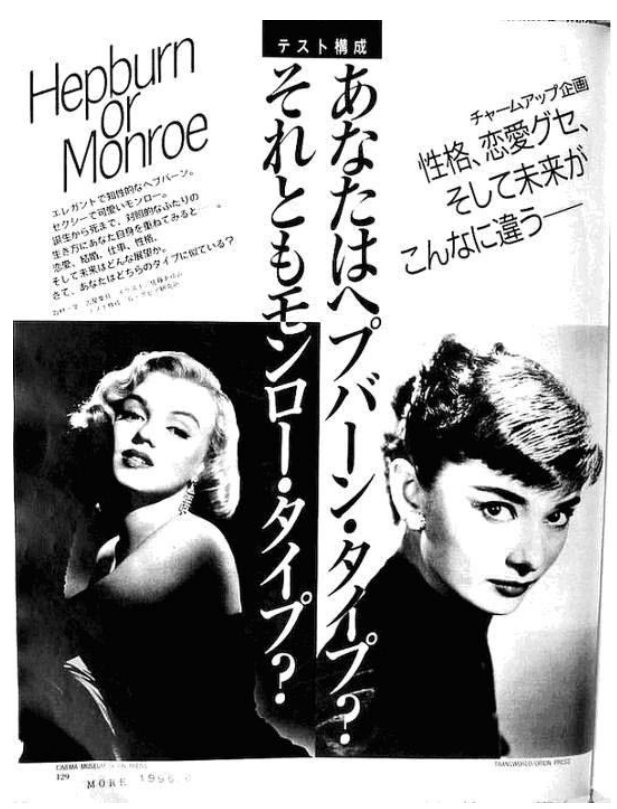

Figure 2: Hepburn Vs. Monroe Test ever compared with any Japanese media stars. She occupies a special position as the 'fairy', as claimed by many popular women's magazines since $1954,{ }^{21}$ amongst the pedestrian stars, representing beauty and transcendental feminine values to Japanese women.

Comparing descriptions of Hepburn and the most popular Japanese idols in women's magazines will help to demonstrate the common ground. Hepburn is seen as an eternally young, ${ }^{22}$ pure, child-like woman, with desirable female elegance and a good work ethic, as well as being a good mother to her son. Amongst innumerable similar articles, More (a magazine targeted at 20 to 25 year old women) published an analysis in 1999, giving ten essential qualities of the most idolised Japanese female pop stars. The first example was the immensely popular Matsushima Nanako, a model, who is also active in television dramas and popular movies. The description of her in the article is strikingly similar

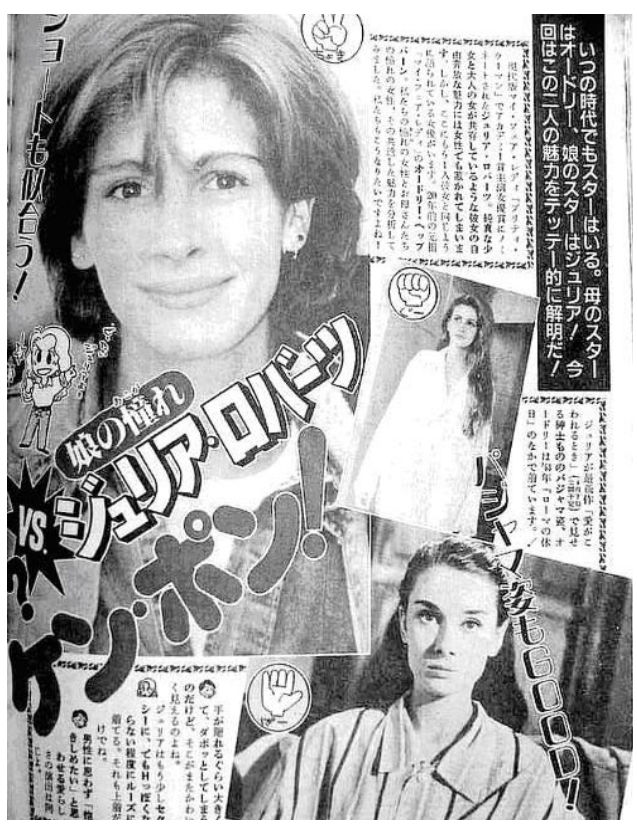

Figure 3: Hepburn Vs. Roberts Test 
to that of Hepburn. Her face is said to be amiably Japanese 親しい, her physique to be slender; she is described as having 'a clear voice, a body with no superfluous flesh and an overwhelming sense of cleanness 澄んだ声とぜい肉の ない体には圧倒的な清潔感があり’ All this has also been said about Hepburn. ${ }^{23}$ Matsushima is also said to have a 'good work ethic' - an attribute also often used to describe Hepburn. Qualities of other popular stars include 'maiden strength', 'personal maturity', 'charisma', 'strength of the eyes', 'strength of continental beauty', just to list a few. Compared with the commentaries on Hepburn, it is not difficult to see the commonalities in popular perceptions.

\section{THE DISNEYFICATION OF HEPBURN}

There are also manuals teaching how to dress like Hepburn, behave elegantly like her, attain her hair style and even travel like her-all indicating the desire to 'become Hepburn'. Dressing up to look like the idolised is a common practice and an important trait in female spectatorship and idolisation. ${ }^{24}$ For the admirers of Audrey Hepburn in Japan, there is no shortage of manuals in the popular press for just this purpose. ${ }^{25}$ In these manual-type analyses of the Hepburn styles, readers are encouraged and given detailed instructions regarding how to do makeup, hairdo, and even dress up as Audrey Hepburn, and even cook with her recipes. (See Figure 4: Manual for Audrey's makeup and hairdo.) Such manuals and feature stories on Hepburn and her styles have become a regular event for popular women's magazines since $1954 .{ }^{26}$ Some of the examples given earlier were published well after her death in 1993. Today, in 2004, a decade after Hepburn's death, her idolisation continues.

But what distinguishes this from dressing up like Joan Crawford ${ }^{27}$ or imitating Betty Grable ${ }^{28}$ in the US is that dressing up like Hepburn is far detached from the Japanese cultural environment. For her Japanese fans Hepburn's European flavour provides yet another layer of dramaturgy. In tradition and cultural terms, there is no previous historical background for Hepburn styles in Japan, making her imitation both topographically erroneous and anachronistic - much the same way that Disneyland and Mickey Mouse are consumed in Japan. In fact, a popular writer Nakatani Akihiro interestingly claims that Audrey Hepburn 'died at the age of 23! [Sic]' By which he means that Audrey Hepburn is idolised in the same way as Mickey Mouse-in that, neither of them age. In deed, Hepburn is mostly presented in

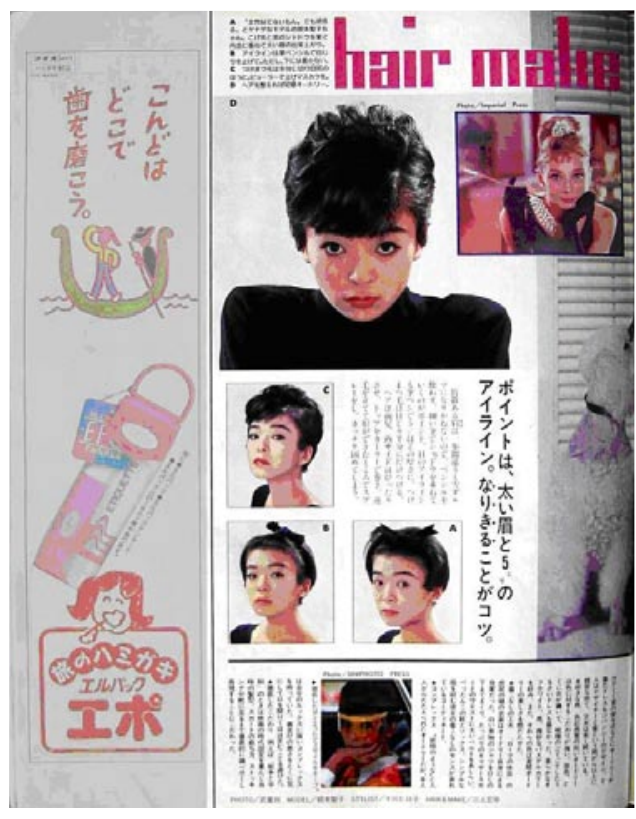

Figure 4: How to look like Audrey by make-up and hairdo 
the visual context of her films from the 1950s and 60s, especially in Roman Holiday, made when she was 23. Like Mickey Mouse, she is also idolised by three generations of fans. ${ }^{29}$ To make the point even more complete, both Mickey Mouse and Hepburn have been culturally de-odour$\mathrm{ed}^{30}$ and now both sit comfortably in the Japanese marketplace.

Today, Disneyland, Audrey Hepburn or Mickey Mouse, present no discrepancies with the 'native' culture-rather, these media products are very much part of the local media staple. Today, it is hard to imagine a Tokyo without Tokyo Disneyland, and Japanese women without their 'Ōdorii' (Audrey), in one incarnation or another. Cultural products such as Mickey Mouse and Audrey Hepburn provided foundations for the localisation of foreign. It can be argued that they have effectively become 'Japanese' - both as media products and, in more ways than one, as cultural icons.

\section{VIRTUALISING THE IDOL}

Hepburn's popularity today in the Japanese media presents important evidence of her posthumous existence, albeit in the binary form that assembles her digitised image. This new lease of life is founded on a new career as an advertising star. Her reincarnation lives on television screens and billboards-the ultimate embodiment of the commercial nature of her posthumous existence. In other words, Hepburn is only 'alive', quite literally, when her audience is buying. Her existence is preconditioned by her own commodification, as a product styled by the 'aura' produced by pre-existing media narratives.

Here 'aura' must also include Hepburn's face, the darkness of her hair and eyes, and the shape of her physique. None exist in physical form today, but together make up the basis for her identification by a Japanese audience. 'Aura' must also include her 'feminine' qualities with a hard working morality, a good mother elegantly fashioned in styles from the 1950s. These qualities will be maintained, and perfected, to suit the current trend, through aspiration and idolisation. The relationship will not be disrupted by uncontrollable public appearances and unexpected public relation disasters - all of which are common hazards of the analogue form of stardom today, and which the fans know only too well. Hepburn's pristine image may even be further refined with future technological developments, together with the creative flair of her future modifiers. This may be done directly, by computer graphics (CG) artists, and indirectly, by the marketers and the market. Indeed, the death of her virtual incarnation can be achieved only by the abandonment of the market-an unlikely scenario, considering how perfect and adaptable she has already become. ${ }^{31}$

The current technology will allow production of future generations of Hepburn. In fact, after the initial success of using a virtual Hepburn, Kirin Beverages used her image again to sell their Gogo no kōcha, or Afternoon Tea, in 1998. The commercial must have been popular and economical, as Kirin continued making advertisements featuring Audrey Hepburn, in one form or another. By 2002, Kirin made at least four Audrey Hepburn commercials for Afternoon Tea. ${ }^{32}$ (See Figures 5-7: Kirin Afternoon Tea commercials.)

Hepburn, however, is by no means the only Virtual Idol-Dick Tracy, Tom Raider and an array of newly 'rendered' 
3D Virtual Idols are becoming permanent residents of the virtual worlds. With the technology behind the creatures becoming increasingly sophisticated, the 'realness' of the Idols is also being perfected by the day. A famous example of such virtual existence is Date Kyoko, the world's first virtual idol created entirely from imagination and pixels.

Date Kyoko (also known as DK96) was launched in 1996 by HoriPro Inc, ${ }^{33}$ not a graphic design firm, but a 'talent (tarento) $^{\prime 34}$ agency. On 21 November 1996, a CD titled 'Love Communication' was released in her name. Apart from audio tracks, the $\mathrm{CD}$ also included video clips of her in motion, walking on the streets of Tokyo and New York (Wolff 1997). ${ }^{35}$ Although entirely virtual without a physical form, Date Kyoko has a profile, a younger sister, a birthday, a

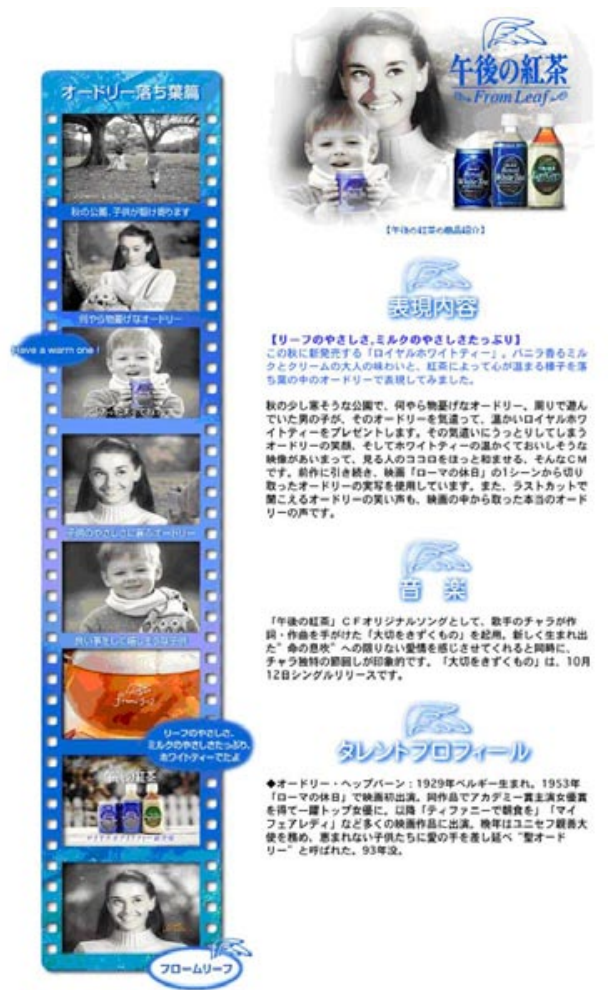

Figures 5-7 Kirin Afternoon Tea Commercials personality and even a career. She was purportedly born to a Japanese couple who ran a sushi bar in Fusso, Tokyo on October 26, 1979. She has a young sister and likes to hang out in a Chinese restaurant called Seiryūmon. ${ }^{36}$ She is a spokesmodel for Oz Interactive, a (physically existing) San Francisco firm that creates virtual worlds for computers. ${ }^{37}$

Date Kyoko eventually faded as a market product. However, she symbolises an important development in the world of idol worshipping. Her worldwide fandom at the time shows that not only is physical form no longer required of idols but, more importantly, that virtual narratives and emotional admiration for a virtually embodied imagination are entirely possible.

Iida on the same subject (and the same Virtual Idol) summed it up well:

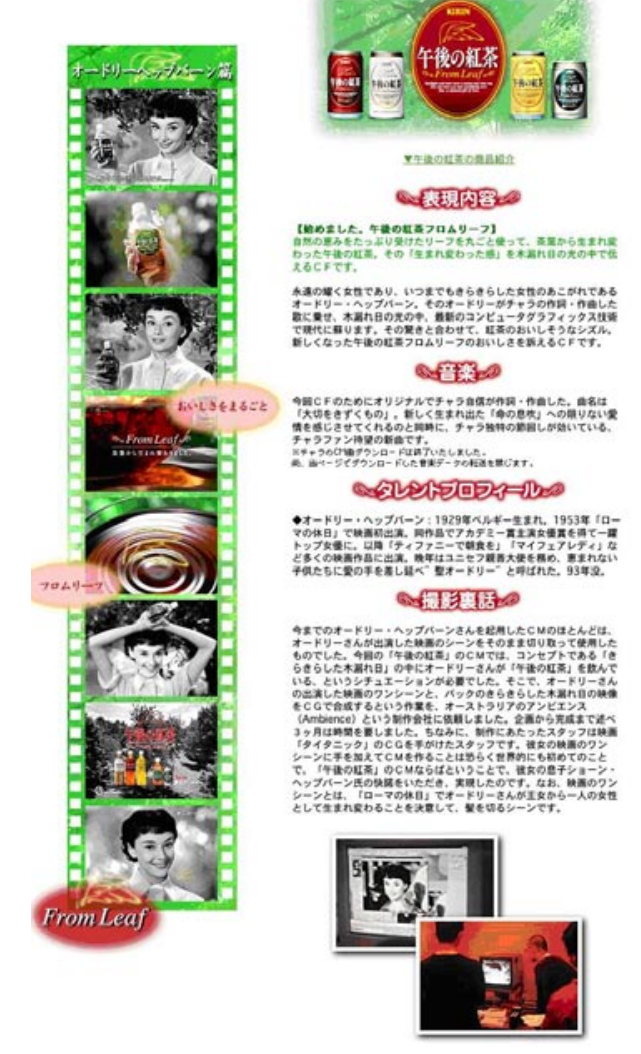


... the fact that the object of one's affection lacked a historical referent does not matter; rather, the pleasure of the products stems from the consumption of images one knows full well are virtual. This marketing of virtuality, however, goes beyond the realm of possessing images of desired objects to the repossession of the self. ${ }^{38}$

In the case of Audrey Hepburn in Japan, the virtualisation does have a 'historical referent' except that the referent itself is also the subject of virtualisation. Both in Japan and elsewhere, the memories of Audrey Hepburn are first of all from a series of performances which are already highly mediated, relative to which her 'real' life story plays a supporting role. The virtualisation goes even further in Japan. As I will elaborate
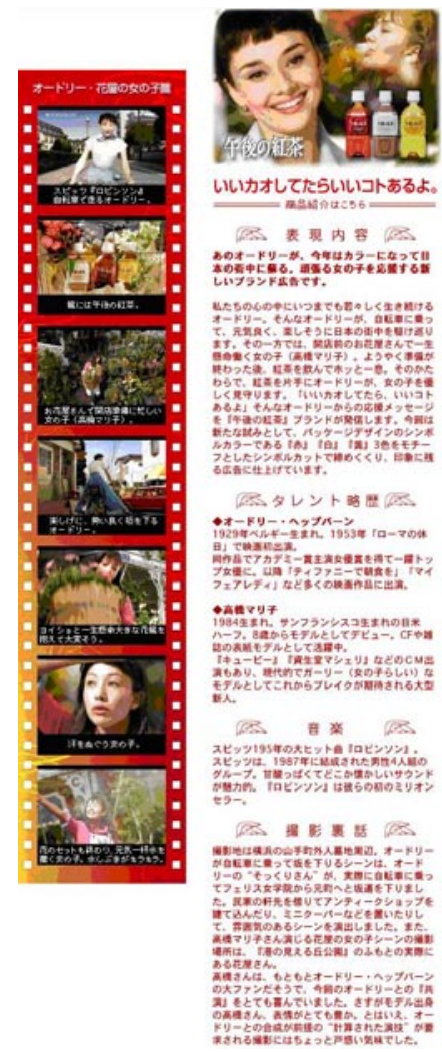

later in this work, she was first replaced by a double, a model who is also her fan, in a television commercial. Then in addition, the 'idea' of Audrey Hepburn has been incorporated in a costume drama, set in Japan's post-war era in a quintessential Japanese locale, broadcasted on the government-funded national television network.

A more commercially successful example is Fei Fei 飛飛, one of the more recent digital creations from a company called e-frontier Inc/Blue Moon Studio. ${ }^{39}$ According to her 'Official Homepage', Fei Fei was born in 1999 in Cyber City Layer 7 Chungking area. She likes the Cyber City layer 23 area where she can see the spring times of Jupiter and Mars. (See Figure 8: Fei Fei.)

Like Date Kyoko, Fei Fei is created with highly sophisticated computer software (Shade) with even more painstaking attention to detail. ${ }^{40}$ And like her predecessor Date Kyoko, she has a career

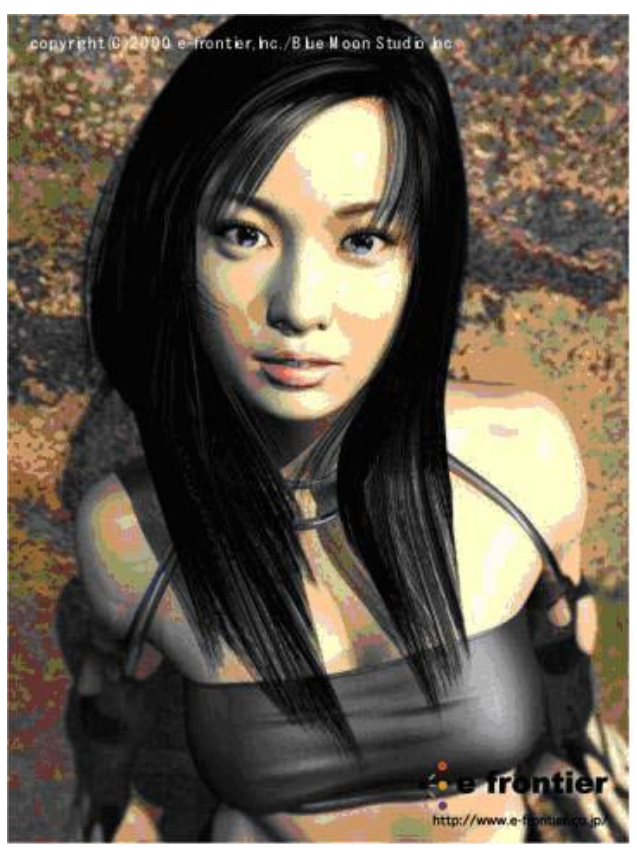

Figure 8: the virtual idol-Fei Fei 
in the commercial world, only more successful and current. Fei Fei is the star in Samsung commercials for its LCD televisions, on both TV and billboards. ${ }^{41}$ (See Figure 9: Samsung commercial.)

Coupled with ever more powerful computer processing and storage capacities, CG programs can now handle complex tasks such as rendering three-dimensional image and movement. The film Final Fantasy: The Spirits Within $(2001)^{42}$ for example, was created entirely on computers, with the help of an extremely sophisticated 3D rendering software called LightWave. In other words, the film was 'built' and 'rendered' with powerful processing chips rather than 'filmed' with cameras. And thanks to the power of technology and human imagination, the images and the movements of its digital actors are so realistic they are comparable, if not better in some ways to the results of a movie camera.

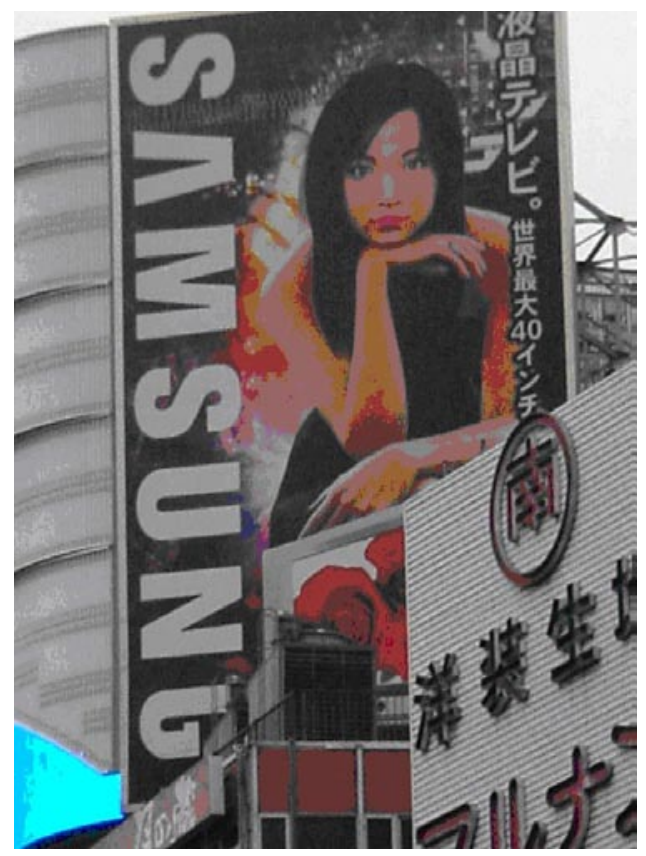

Figure 9: Fei Fei presenting Samsung, on billboard at Shibuya Crossing, Tokyo
Here is how the film was reviewed on a popular film site Hollywood.com

... now there's a whole new way of looking at CGI technology-'hyperReal' human characters. That's right. Computer-generated people that look just as real as any Tom Cruise or Julia Roberts. ${ }^{43}$

Indeed, not only do they 'look' comparable to stars of the physical world, they are capable of inducing similar kinds of emotional admiration in some, in the same manner as Tom Cruise or Julia Roberts. According to the film's producer, Christopher Lee, the main character Dr. Aki Ross was voted one of the 50 sexiest people in Maxim magazine. ${ }^{44}$

Iida draws a connection between the Virtual Idols and the Japanese Purikura (a Japanese word derived from the English 'print club'). Purikura was extremely popular in age groups spanning from

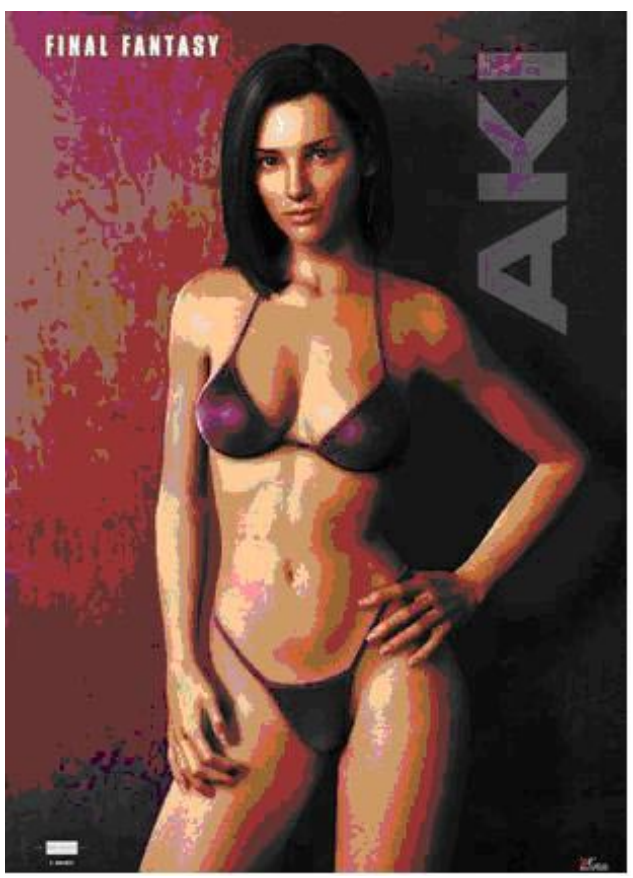

Figure 10: Dr. Aki, both the role and the performer. 
school children to university students. It is basically a specially made camera typically installed in game arcades or sometimes specialised Purikura game centres. It allows the 'player' to take photos with instant printouts of many small duplicates (mostly litter stickers of small stamp size). Many schoolgirls have a collection of hundreds of those Purikuras, tiny photos of themselves, often taken with various friends.

It can be argued that it is a form of self-admiration and virtualisation, as the prints not only are portraits of the self, but the mechanics (its instantaneousness, low cost, various forms) and popularity, shorten the process of a personal narrative. Purikura also allows the player/ the self to stage and perform an otherwise forgettable moment-or rather, the medium allows the participants to perform for the sake of performance just because the medium is there. The fun of this game is not derived from any difficult techniques - there are none - but from the fantasy in which the self is the star. As lida puts it:

... the core pleasure of this form of play $\ldots$ is acting in the context of the framed narrative and possessing a purely imaginary sequence of the story of oneself that has little to do with the outside world. ${ }^{45}$

\section{Further, it}

... Suggest $[\mathrm{s}] \ldots$ an enclosure of the pleasure loop, the emergence of a form of pleasure induced by artificially created images; although specific commodities are chosen to be admired, the true object of this self-referential pleasure economy is one's own consciousness and its ascription of value to particular objects as worthy of admiration. ${ }^{46}$
Thus in the same light, neither the current fast-developing imaging technology nor the market appetite will limit the possibility of Audrey Hepburn becoming an infinite number of digital bytes, re-represented, re-reproduced, re-cultivated as pin-ups and as a media star, immortalised in the post-real world.

This is also why the idolisation of Audrey Hepburn in Japan is vastly different from that of, for example, Julia Roberts, Meg Ryan or Brad Pitt. First, these current American pop stars are still physically alive. Their parallel existence cannot be either modified or reconstructed easily. Because their analogue existences leave traces in the media, their personal lives produce or induce materials in the gossip columns and paparazzi photos. This provides documentary-like evidence; creating continuing history and narratives, which in turn 'authenticate' them. Therefore it is difficult to construct parallel versions of the living idols completely in media. ${ }^{47}$

Audrey Hepburn in Japan is not a simple 'simulation' of the 'real'. The virtualised Audrey Hepburn is a reproduced image of the Hollywood actress, which also existed mostly in mediated forms. Both are first of all media products-neither are simulations of the 'originals'.

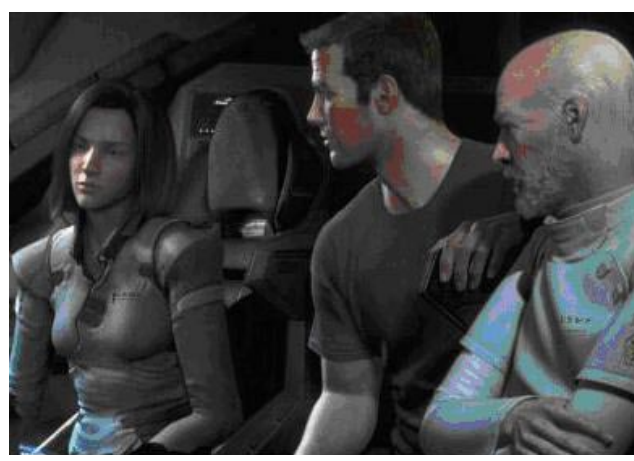

Figure 11: A still from the movie Final Fantasy, a movie produced entirely on computers. 


\section{THE PRODUCTION AND CONSUMPTION OF AUDREY HEPBURN}

Audrey Hepburn started appearing in commercials in Japan as early as May 1971, for Japan Exlan Co., Ltd. 日本エク スラン工業 (株), selling a wig, a booming fad at the time. ${ }^{48}$ The shooting of the commercial originally planned to be filmed in Japan, reportedly had to move to Rome, because Hepburn did not want to leave her one-year-old child behind. It was eventually filmed around the old city in Rome, showing Hepburn strolling in front of a classic Italian backdrop, with the seasons morphing in the background. During the commercial, Hepburn utters only one word: Variie (Varié), the name of the wig. The commercial reportedly cost $¥ 50,000,000$ (US\$139, 895). ${ }^{49}$

The original plan to shoot the television commercial in Japan was not without significance. Hepburn was to sell a Japanese local fad, in an 'authentic' Japanese milieu with clearly defined seasons as the backdrop - a quintessential Japanese motif-morphing through in less than 30 seconds. ${ }^{50}$ She was to be seen strolling in old quarters of Kyoto (instead of Rome), alongside kimono-clad maiko and geishas in Gion and Pontochō through the picturesque four seasons, from falling cherry blossoms to the stone garden covered with snow - just as the American cellist Yoyama would do for Suntory whisky later in 1990s. (See Figure 12: Suntory whisky with Yoyama.) The commercial would have given Hepburn a Japanese 'aura' from the very beginning of her commercial career in Japan.

During the entire 1970s, Hepburn starred in only two feature filmsRobin and Marian (1976) and Bloodline (1979). After that, she appeared in one documentary-style film, They All Laughed

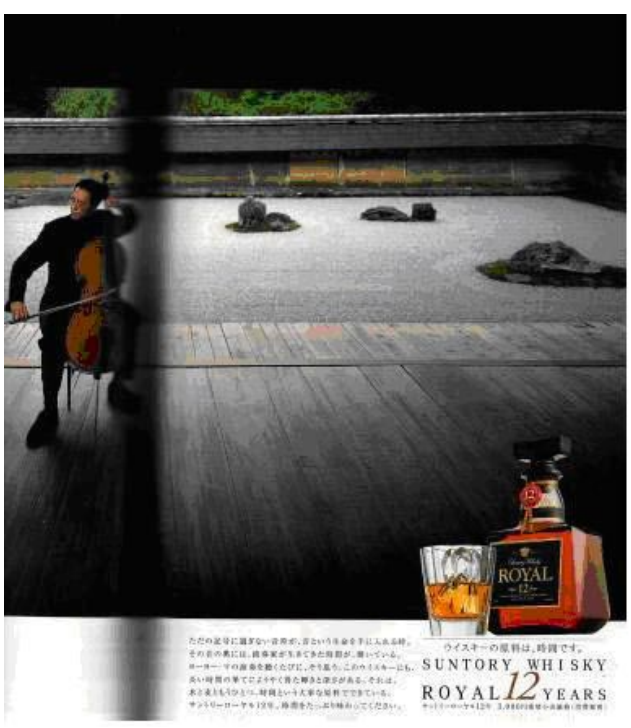

Figure 12: Suntory Whisky with Yoyoma

(1981), and in a made-for-television movie Love Among Thieves (1987), a sequel to her famous 1966 film How to Steal a Million. None of these later films are as memorable as the ones she starred in the 1950s and 60s. Hepburn's last movie was the not-so-well-known film Always (1989), directed by Steven Spielberg in 1989, at which time her current fans under thirty today would have been less than 15 years old. The contemporary Hepburn fans have seen her far more often on Japanese television commercials, billboards and magazine covers than in Hollywood films. Thus, it can be argued that the Audrey Hepburn in the Japanese marketplace is more of a transformed television idol than a Hollywood film star.

Ten years after her 1971 commercial, the then 52-year-old Hepburn appeared in another commercial for Ginza Lizaa trendy fashion boutique during the heyday of the Bubble period. Josei Jishin, a magazine with a readership predominantly in their mid-20s and over, reported: 'Hardly looking 52, she 
exhales an elegant mood, and shows off eight costumes' ${ }^{51}$ (Josei Jishin 1982). In 1987, she appeared in a commercial for House Foods Co. 八ウス食品工業. ${ }^{2}$ This was probably the end of Hepburn's appearances in Japanese commercials by her own (living) consent. However, her death in 1993 in no sense brought an end to her career as an advertising star in Japan - in fact it continued, with her popularity going through spurts of revival throughout the years that followed.

In 1994, hardly a year after her death, Audrey Hepburn was reincarnated, younger and more active in the Japanese marketplace. Her image was used in commercials targeted at young females, such as the one for VO5 hair care products. ${ }^{53}$ The pragmatic decision to recycle her from old Hollywood films and wake her from the dead was a result of market research. According to a survey conducted by WOWOW (a subscriptionbased satellite TV station), her popularity did not even fade, much less disappear, after she died. She continues to rank first as 'the most remembered actress' and her most famous screen appearance-Roman Holiday, as the most memorable by far. ${ }^{54}$ Based on these survey results, it is not difficult to see why advertising agencies would decide to (re)use, and reconstruct her as their eternal heroine.

The periods of revival of Hepburn in the media are sometimes called minibooms 'chotto shita boom'. ${ }^{55}$ These minibooms have inspired magazines such as Anan, Non.no, More, Crea, Josei jishin, Shükan Josei, Josei Seven-all geared toward female readers. Even men's magazines like Playboy Weekly ran articles on her. To supplement men's comparatively limited knowledge of Hepburn, the Japanese version of Playboy even published a manual on 'basic knowledge for Hep- burn Mourning'. ${ }^{56}$ If a manual was not enough, people could take a guided tour to Europe and the US for a living experience of mourning a dead idol. ${ }^{57}$

Hepburn's commercial value in Japan seemed to increase once her physical existence vanished. An entire industry arose after her death. Magazines have published innumerable articles on her life, commentaries on her films, analyses of her lifestyle, manuals on how to mourn her, and many more on how to be her. In women's weekly magazines, one can regularly find manuals and analysis on how to dress, make up, and have hairdos to look like her. There have even been detailed A-Zs of almost every aspect of her life, including such items as 'Diet', 'Flower', 'Hotel life', 'Intelligence', even 'Neurosis(shinkeishitsu)' ${ }^{58}$ The entry under ' $\mathrm{J}$ ' was, of course, 'Japan', said to be 'a country which Audrey favoured, where the film Roman Holiday was especially successful, and where Audrey Hepburn also starred in a television commercial for a Japanese fashion maker ${ }^{59}$ Apart from the demand for knowledge about her, and the knowledge needed to be like her, the knowledge industry (predominantly the English language teaching industry) also recognised the commercial value of Hepburn's image. Berlitz, one of the longest running English schools in Japan, employed one of her most famous screen appearances in Japan, a still from Breakfast at Tiffany's (1961). (See Figure 13: Berlitz's Audrey.)

Perhaps the most creative commercials featuring her appearance are the ones made by Kirin Beverages for a canned tea called Gogo no kōcha (Afternoon Tea). Kirin Beverages is one of the biggest beverage companies in Japan. In 1998, the company made a hit commercial showing Hepburn drinking Gogo no $k o ̄ c h a$, in a scene cut from her first Oscar 


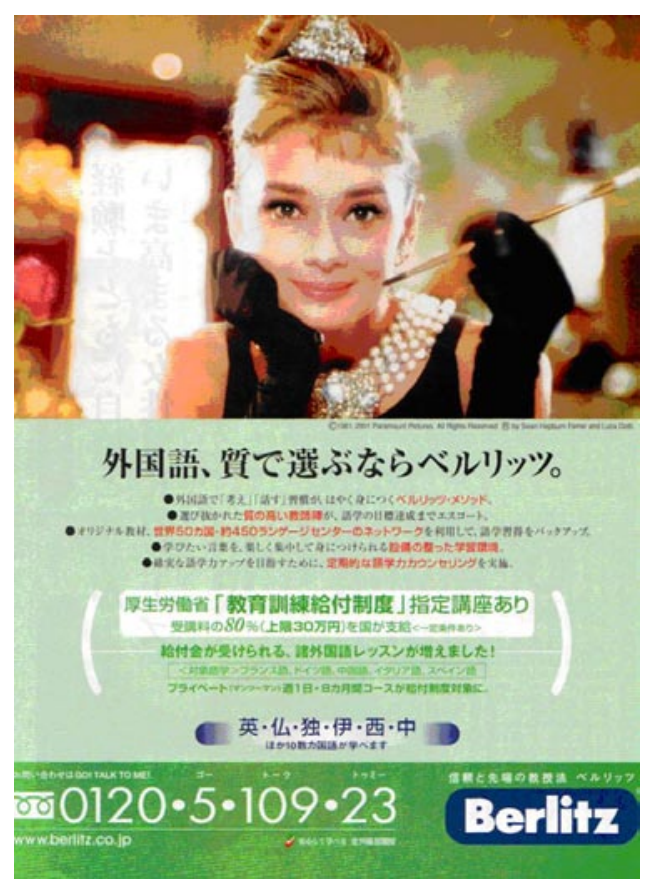

Figure 13: Berlitz's Audrey

winning film Roman Holiday. ${ }^{60}$ The commercial was an industry first, not only because it used very complex computer graphics, but also because it was the first commercial to re-employ a digitised 'Hepburn', to re-enact a scene from an old film for the purpose of selling a product. The commercial was again not made in Japan, nor in the surroundings of European high cultures, but was composed and fabricated in Australia by a CG company called Ambience from Sydney's North Shore (Kirin Co. 2001)a. Hepburn did not attain another Oscar for her performance in the tea commercial, but the implication of her virtualised appearance in the consumption of media content is perhaps even more significant.

Kirin Beverages clearly has recognised the potential market value of the digital version of Audrey Hepburn, and has since then made more advertisements using her image for this particular tea. In 2000, with another scene cut from Roman Holiday, and the same technique and apparatus, Kirin made another TV commercial (Kirin Co. 2001-b). The success was highly visible, especially in Tokyo's fashionable city centres, such as Ginza, Harajuku and Shibuya. At the end of each year Tokyo is imbued with a 'Christmas atmosphere' that has no relation to Christ or the Virgin Mary, but everything to do with the latest fashion trends and romance. At the end of 2000, on the exterior surface of the entire Tōkyū department store building/Shibuya JR (Japan Rail) station, hung a massive billboard poster showing Hepburn drinking the canned tea-Gogo no kōcha.

\section{GA-RII (GIRLY) ガーリー CULTURE AND PIZZICATO}

Having gone through various transformations, Shibuya's status as a fashion centre continues today. The fashion lingo 'Shibuya Kei' describes the young people who principally shop, play and wander in Shibuya. In the early 1990s this area was dominated by 'Ga-rii' culture. Written in katakana, Ga-rii is a 'loan word' from the English 'girly' or 'girlie'. For the most part, it just meant 'feminine', or onna no ko rashii. For the Girly girls, in addition to the usual kawaii or cuteness, and purity (junsui), it was also important at same time to be stylish, fashionable, and to look intelligent (Chiseiteki). ${ }^{61}$ The young women of the late 1980s and 90s consumed not only big European brandnames, ${ }^{62}$ but also more knowledge. As a marketing strategy, department stores such as Seibu offered a variety of courses to inculcate in young women knowledge of western habits and customs, and opened in-house art museums to attract the increasingly cultured consumers. ${ }^{63}$

Although 'Shibuya-Kei' has now 
morphed into new styles and trends, Girly culture was its main component in early 1990s. For some, Girly fashion would be typically 'postmodern' - it mixed and borrowed heavily from fashions of the 1950s and 60s. Amongst the phenomena of Girly culture there was a zealous consumption of the so-called Hepburn styles. An example of this was the band named Pizzicato Five which only went out of fashion in early 2001. The Pizzicatos were a group of ardent impersonators of Hepburn, and just like Girly fashion, their style of music was a collage of rearranged nostalgia. One of their songs was even entitled 'Audrey Hepburn Complex'. ${ }^{64}$ Girly girls liked both the Pizzicatos and Hepburn, for they complemented each other, helping to turn each other into something conservatively contemporary; more than just a style dug out of their mothers' old closet.

Thus this 'overwhelming boom' in the revival of Audrey Hepburn is not just because of the continuing nation-wide female admiration for her image. It is also closely linked to the revival of nostalgic fashions around the early 1990s. Moreover, this more current generation of Japanese consumers of the 'Hepburn styles' is also influenced by their own mothers and women of earlier generations. This 'nostalgia' is not merely for the exotic, but rather for a version already domesticated by the previous generation. Thanks to the marketers, the later construction of Hepburn's image is now linked to locally manufactured styles, and products. Therefore Hepburn, with her perceived exoticisms from either her European background or her Hollywood film career, is not really the motif of the contemporary Hepburn style. Rather, her reappearance and reconstructed image signifies, in Jameson's words, 'nostalgia for the present', used as a sales pitch for 'now-ness' ${ }^{65}$ In other words, the Japanese Hepburn has been localised and detached a couple of generations away from the Hollywood one. Today's Hepburn in Japan is a contemporary construction of a Japanese image of her, in the same way that 'armchair nostalgia' is produced for advertising targeted at young people. ${ }^{66}$ (See Figure 13: Asahi's remake of a soft drink from early Showa (1926-1989).)

\section{THE QUESTION OF COMPATIBILITY}

In many women's magazines Hepburn has been repeatedly enshrined as yōsei 妖精 or 'fairy', implying the perpetuation of her popularity and reverence for her beauty. In one of the very first Japanese articles about her, published in April 1954 by All Yomimono オール読物, Hepburn was already idolised as a fairy. Her film Roman Holiday was an unexpected hit for the Hibiya Movie Theatre, where the film was released and where it had a five-week long run. ${ }^{67}$ What followed was a nation-wide trend to imitate Hepburn's fashion from Roman Holiday, including her hairstyle, ${ }^{68}$ her clothes, and even the kind of bicycle she rode. A couple of months later, a contemporary popular culture critic, Hanamori Yasuharu, wrote an article criticising the trend of imitating Hepburn, and gave detailed analysis of why it was impossible for Japanese women to achieve Hepburn's style by imitation. The article, entitled ‘Dissecting Hepburn ヘップバーンを解 剖する', gave both cultural and anatomic analysis of what Hanamori saw as a fatal marriage of style and substance-how slacks (the ones Hepburn wore in Roman Holiday) do not suit Japanese women whose physiques would make the outfit 'unbalanced', and how tatami rooms 


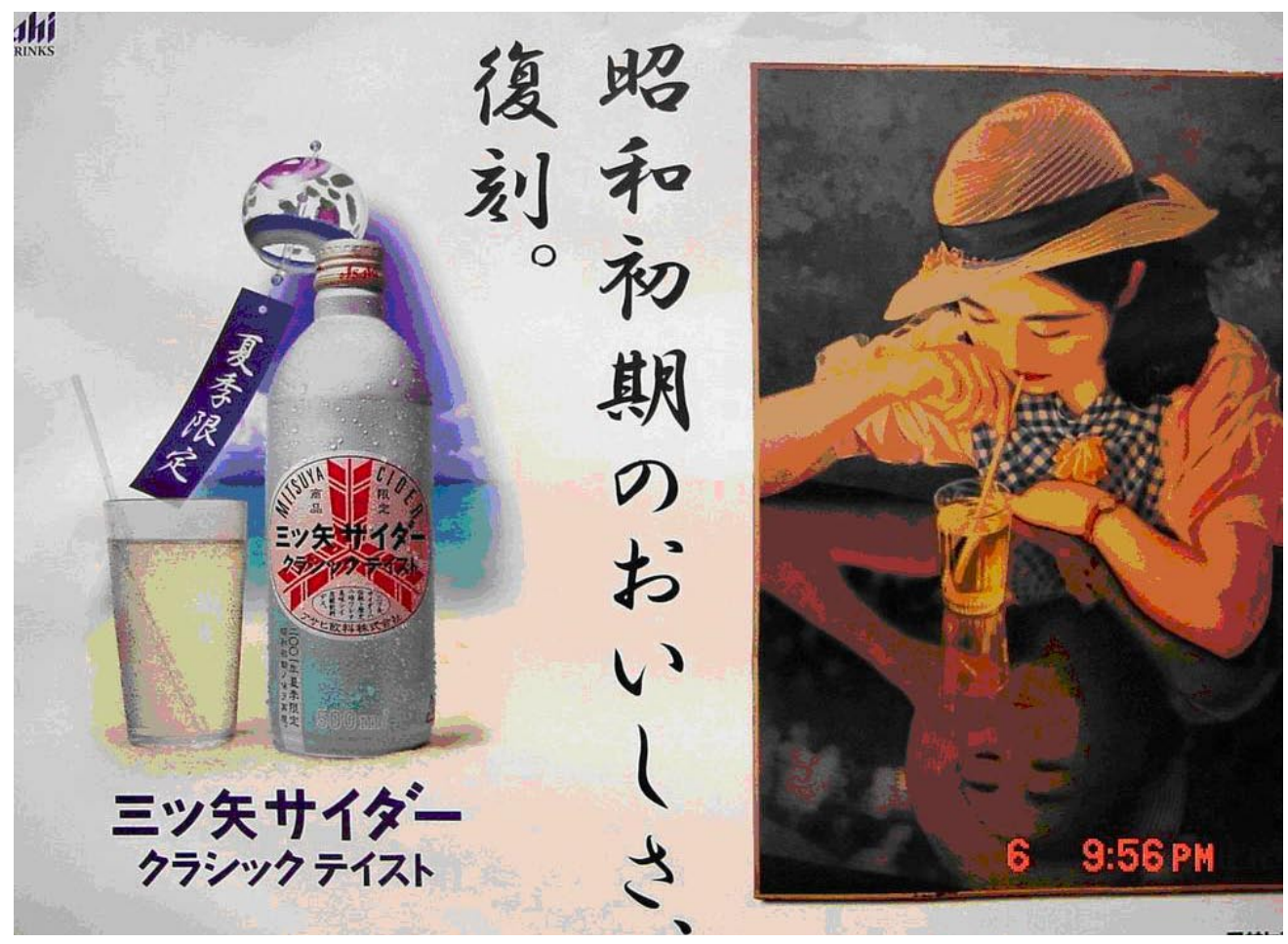

Figure 14: Asashi's production of nostalgia sold for a limited time, tasted distinctively non-distinctive from sugar added water.

would kill the 'Hepburn beauty'. ${ }^{69}$ Hanamori asked readers to imagine sitting Hepburn in a Japanese room where, the cultural critic concluded, the 'Hepburn beauty will just die!' ${ }^{70}$

It seems that Hanamori's early criticism missed the point of the 'postmodern' phenomenon half a century later. Developments over the following decades prove that neither cultural nor anatomic differences would prevent Hepburn from becoming part of the Japanese female psyche, and those 'imbalanced' slacks and tatami rooms fit both the Japanese girls and their Hepburn imaginations just fine. In fact, the popular cultures developed in the half a century that followed Roman Holiday, indicate that Japanese women have acquired a taste for things with European flavours. The 'Hepburn-style' has evolved into some- thing that suits the local women. Hepburn, after all, is a 'fairy', who proved capable of metamorphosing according to the aura around her. For the image of her in Japan, perpetuation is an essentiality, history is irrelevant, and locale a matter of indifference.

\section{THE TRUE REBIRTH OF AUDREY HEPBURN (IN A CANNED TEA)}

In 2001 Kirin made yet another commercial featuring Hepburn, this time in colour. Further, Hepburn had a co-star, an actress of hybrid descent (Japanese and American, or nichibeha-fu) Takahashi Mariko, an archetypal model of Ga-ri fashion. (See Figure 15: Takahashi Mariko.) The commercial claims to be 'an encouragement for hardworking women', and is another acrobatic compu- 
ter-generated collage. It cut and pasted another scene from Roman Holiday, this time combined with real time shooting and living people. Audrey Hepburn's alter ego this time is not just the Hepburn from the archives. It is combined with a look-alike (Kirin Co. 2001-b). To make it, the scene was first shot with the lookalike and then, with the help of digital technology Audrey Hepburn's face was inserted in place of that of her double. The commercial was shot in Japan but with European-esque surroundings. The filming site was Oka kōen in Yokohama, a park opened in 1962 on the ruins of an old English military post. The flower shop in the commercial is a working florist. The first shot in the commercial, showing 'Hepburn' racing down the hill, was filmed in the vicinity of an old cemetery for past expatriates, which all fit terribly well, without irony, with the theme of Hepburn as 'the fairy watching

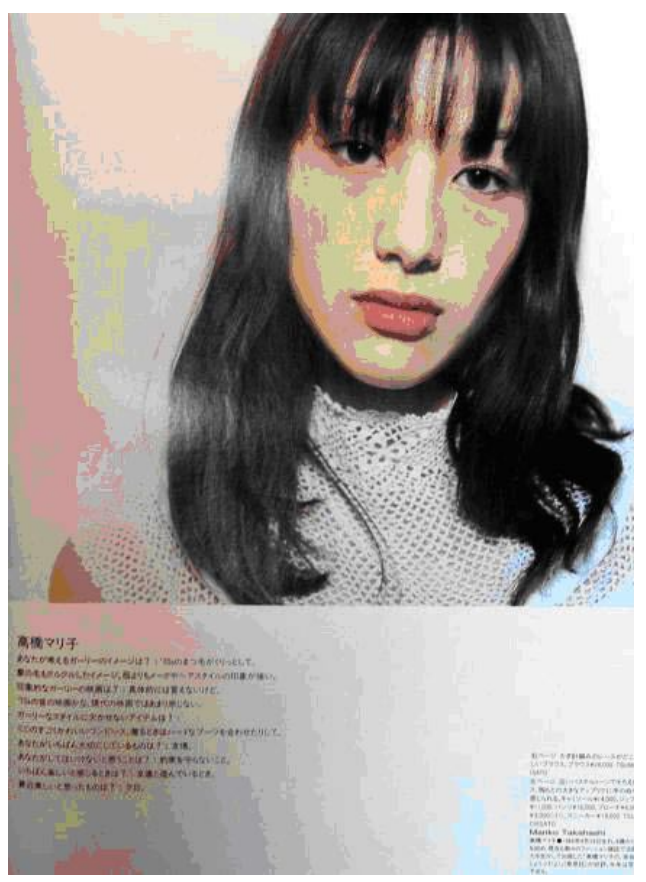

Figure 15: The model 'girly' girl: Takahashi Mariko over' a hardworking girl - that is her fan, Takahashi Mariko. It is hard to pick out which part of this commercial is fiction and which is 'real'.

This commercial has a number of significant implications. It is the first 'Audrey Hepburn' commercial set in Japan, finally putting her in the Japanese milieu, giving a newly acquired pedigree of local-ness to Hepburn's image. Secondly, it is shot in colour, in a current and known location. This replaces the previous visual rhetoric of nostalgia, signifying a departure from the historical and the European/American background, while giving it contemporary Japaneseness. Thirdly, not only did she become a contemporary in this television commercial, but she also acquired a Japanese co-star, thus putting Hepburn on a par with a Japanese idol. Fourthly, her reputation as a 'fairy' is finally materialised and commodified, signifying a departure from her old black and white, nostalgic archival identity. It marks a point in time where history becomes irrelevant. 'Hepburn' and imaginations based on her from this point on becomes accessible and modifiable. 'Audrey Hepburn' can now be entirely locally produced according to market requirements at the time, locally presented and selling a local commodity. The image of Audrey Hepburn will continue to be interwoven into the local cultural tapestry and contribute commercial value to the local economy by being the fairy of female aspiration, representing beauty, talent and the forever intriguing combination of nostalgia and now-ness. (See Figure 16: Sharan and Pasona advertisements, 2003.)

Regarding the visual presentation of pseudo patina in mass merchandising, Appadurai describes how the idea of 'nostalgia for the present' is being used as a technique in advertisements 


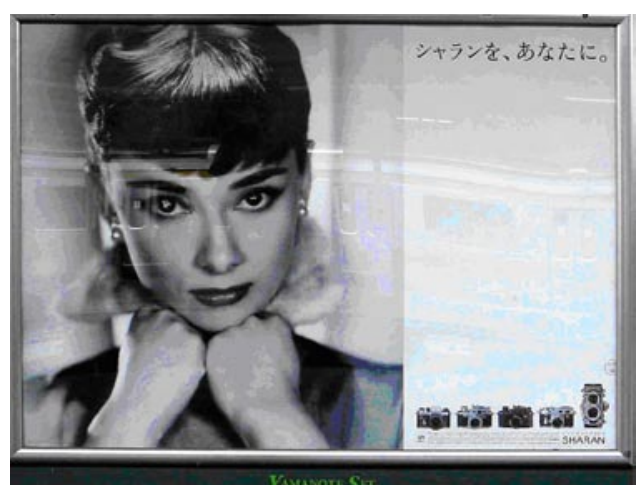

Figure 16: Hepburn presenting Sharan, a series of cameras with retro designs from Cannon.

targeted at young consumers. It is used as a 'stylised presentation of the present as if it has already slipped away', which underlines 'the inherent ephemerality of the present'. This technique is taken one step further in the Afternoon Tea commercials, which repeatedly re-employed Hepburn's images, and effectively created separate narratives for her. Not only are these commercials representations of 'nostalgia for the present' that' underlines' the ephemerality, but they undermine the idea of time altogether. The reconstructed narratives give the current trend for 'present nostalgia' instant patinas and at the same time make (re)rendition of history immediately applicable to any given era and locale. This not only signifies that culture is indeed an object which can be constructed, exchanged, and then bought and sold, but also that identities can be effectively digitised. The consequence is that it makes redundant any idea of a hierarchical realness, not only in terms of original/copy but also in terms of history and now. ${ }^{71}$ It repudiates the traditional inaccessibility of a historical idol and essentially updates and democratises it, by making the reconstructed image impervious to the idea of authenticity, to historical narrative, and topographical settings. ${ }^{72}$

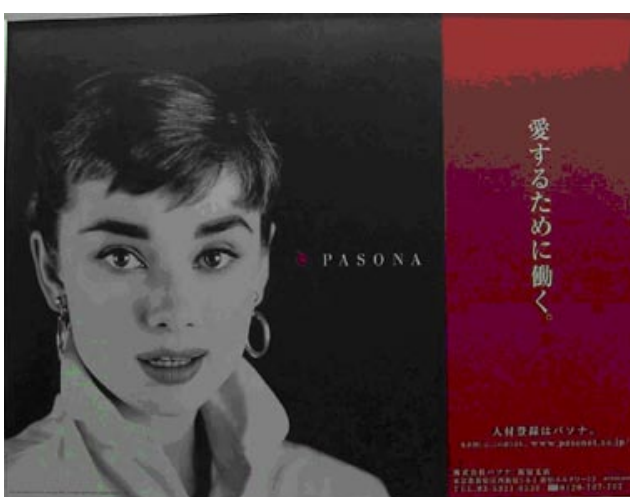

Figure 17: The face of Audrey Hepburn, as the face of working women, for Pasona, a temp agency

Audrey Hepburn and the images of her are now subject to future modifications at the will of the marketplace. Since the first Kirin commercial using a digitalised Hepburn, it has acquired new narratives. History, or in Hepburn's case, Roman Holiday and Breakfast at Tiffany's already novelties themselves, became part of the mediated aura, reusable for new narratives constructed to lend sense of drama to the purchase of everyday consumer goods.

\section{HEPBURN NATIONALISED}

Just to make history and topography more irrelevant to the idea of Audrey Hepburn than they already are, NHK, the government-founded conservative television network, produced a serialised TV drama called 'Audrey' or 'Ōdorii' in Japanese. Aired between October 2000 and March 2001, it achieved a rating of $20.5 \%$ in the Kantō area (East Japan). The scheduling clearly indicates that the drama was targeting mostly housewives. It was shown first for 15 minutes in the morning from 8:15 to 8:30 each day of the week from Monday to Saturday. Then the entire week's drama would be compiled and re-shown on Saturday mornings 
from 9:30 to 11:00 am on NHK's Satellite 2. (See Figure 18: NHK's Ōdorii.)

The story of this Audrey started in 1953, the year Audrey Hepburn starred in Roman Holiday. A translator named Haruo lived in Kyoto, which used to be called the Japanese Hollywood. His wife Aiko gave birth to a baby girl, later named 'Audrey', or in Japanese Ōdorii. Little Ōdorii was being brought up speaking English with Haruo in Kyoto. Two years later in 1955 Audrey Hepburn's Roman Holiday won critical acclaim in Japan. ${ }^{73}$

The TV drama was a typical jidaigeki (costume drama), a genre consisting mostly of history soaps. These

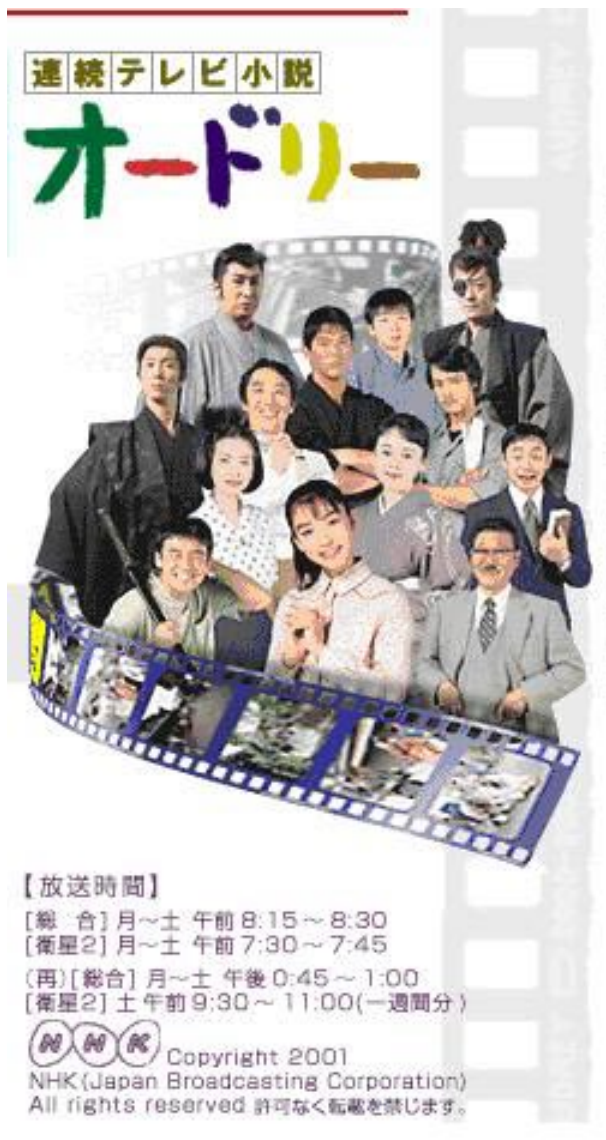

Figure 18: A Japanese narrative for the Japanese Audrey, courtesy of NHK. costume dramas often narrate history in more ways than textbooks can perfect and reach wider audiences through television. The show Ödorii is not about Audrey Hepburn, but about the dramas of Haruo's family in Kyoto. The setting is quintessentially or perhaps 'exotically Japanese ${ }^{\prime 74}$ with most of its costume being the traditional kimono. The show tells the story of post-war Japan and the growing up of the Ödorii generation. Here, Audrey Hepburn's name is treated as a symbol, localised with a Japanese historical background, then inserted with a Japanese face, not so different to what Kirin has done in their commercials. Ōdorii would have grown up and by the time the show went off air in 2001, she would have been 48 years old. If she married around 25 and gave birth in the following couple of years, her daughter would have been one of the Girly girls and a Hepburn fan. The Odorii show tells a post war history in a most iconic Japanese Kyoto, with three generations of devotion to a Hollywood fairy. It might not be the most entertaining, but it gives a pseudo-historical background to what is in vogue. Importantly it makes Audrey nostalgically Japanese, in an environment 'exotically' Japanese, renewing a reconstructed 'experience' for the current Audrey fan - an 'experience' not only they did not have, but an experience itself that never existed. If Kirin's new commercial signifies a materialisation of Audrey Hepburn's virtuality (and her 'fairy' status), then Ödorii provides the instant patina for this virtuality.

\section{CONCLUSION}

More than a decade after her death, the idolisation of Hepburn is well and alive in 2004. The sold-out exhibition aptly titled 'Timeless Audrey'75 in Tokyo, which is 
now touring the nation until 2005, seems to signifying further the irrelevance of time to the 'fairy', and confuses further the order of history. It is no longer meaningful to argue for a 'real' and 'authentic' Audrey Hepburn. The best we now see is the 'real' Hepburn in an exhibition about the 'timelessness' of her idolisation reflected in the various visual representations of a beautiful fairy in different roles.

In a fascinating essay written on Postmodernity and Tokyo Disneyland, Yoshimoto Mitsuhiro argues:

Disneyland cannot be parodied because as it is a simulated fatal space, it is also already a parody of what it simulates ... Consequently the Tokyo Disneyland cannot be either an imitation or a reproduction of Disneyland in Los Angeles: it is a 'real' - that is, simulated Disneyland. ${ }^{76}$

And:

... Tokyo Disneyland epitomizes the cultural logic of postmodern Japan which has nothing to do with the logic of Americanization. On the contrary, the Tokyo Disneyland, superficially the epitome of Americanization, completely repudiates the notion of Americanization as the dead remnant of modernization theory. ${ }^{77}$

Nor is the Japanese Audrey a 'Hollywood-isation'-both Disney and the current reconstruction of Hepburnthey are mediated imaginations and commercialisation of cultural icons. As I have shown above, the Japanese marketplace has reconditioned the Hollywood Hepburn into one that has most effective commercial value and has given her image an appeal that fits the local and current Japanese female consumers. It is not as simple as another example of Americanisation and/or westernisation of Japanese culture. Hepburn's initial popularity in Japan may be because of a certain amount of admiration for western consumer cultures in the early days of the 1950s when her films started to win popularity worldwide. But her more recent iconic status in Japan is very much a local commercial and cultural product. Scholars such as Brannen, ${ }^{78}$ Yoshimi $^{79}$ and Yoshimoto ${ }^{80}$ argue that Tokyo Disneyland is a Japanese Disneyland, which makes Mickey Mouse in Japan a Japanese Mickey Mouse, both culturally and economically. ${ }^{81}$ By the same token Ödorii, indeed can only be a Japanese Audrey.

The Japanese Audrey presents us with an interesting case of cultural reproduction in a seemingly incompatible and improbable cultural environment. It is a successful example of how, with the collaboration of willing consumers, marketers are able to regenerate interest in old narratives, and reproduce these with contemporary relevance. In the case of Audrey Hepburn, Japanese marketers have localised or 'domesticated' what might have been a foreign cultural product into something intrinsically local. They have given it a new lease of life, in a new era, in a new environment. Thus the 'Hepburn of the day' acquires renewed commercial value and continues to inspire consumers.

Moreover, the marketplace has effectively made it possible for identities to be part of cultural production, virtual or otherwise. The Japanese Hepburn means that an identity, body and soul, can be digitised and modified without losing 'integrity', by nature of the progression of digital media. In fact, as I have demonstrated here, the traditional concepts of cultural integrity and authenticity are deemed to be irrelevant in the case 
of digital reproduction. The postmodern ideas of simulation, of simulacra, and of the hyper-real, problematise recent social and cultural phenomena such as the reproduction and localisation of Audrey Hepburn. However, these different versions of 'Audrey' (in different commercials and in different dramatic uses) are incomparable. From the point where her image is digitised, the concept of hierarchical realness effectively becomes redundant. For in digital media, no one copy can be more real than any other.

Thus 'Audrey Hepburn', by definition, is 'virtual', in more ways than oneshe existed mostly in the media when she was alive; and was further mediated to the point of reconstruction when she was dead. 'Audrey Hepburn' is from the first a name created for the media. Her 'real' name Edda van Heemstra Hepburn-Ruston is virtually unknown.

Virtual identities are possible not only as aliases. At the cultural level and in terms of consumption, they help the market and the consumer to adjust to current trends. The possibilities of reproducing identities not only give marketers the ability to constantly reposition their products, but also enable the consumers to switch at appropriate life stages between products and brands, and hence identities.

In an era in which consumer products have come to resemble each other in functionality, in quality and even in appearance, the only thing setting them apart is 'branding', a process which arguably started with advertising of various kinds. With poignant examples, Twitchell demonstrates that the only thing advertising sets out to do (and is doing well) is creating 'stories' and 'meaning' for the products it tries to sell. ${ }^{82}$ That is why an Audrey Hepburn from the 1950s is being used for commercials to sell a tea she did not know existed. Kirin Beverages Co. has successfully borrowed, and in the process re-authored Hepburn's aura, the associations she has with European good taste, romance in old films and her perpetual youth.

As the protagonists of styles and role models of consumption, media stars sit comfortably with advertising at the tip of the 'story' and 'meaning' creation. Klapp recognised during 1960s that styles 'are a set of props for casting oneself in a character, rather than a means of expressing one's true self', while 'idols provide a shared temporal journey of identityseeking for the fans' ${ }^{83}$ Hepburn is a good example of this process. The Japanese adaptation and resuscitation of her screen life is a pivotal story of everyday consumption. Amongst vast varieties of goods, only brand association or the stories and meaning created by media can tell the tale of difference - not in what they do (their function) but in what they imply; in the consumer's taste and their everyday 'dramas' of consumption in such things as drinking a canned tea.

Japan's Audrey Hepburn is just another example of how mass aspiration either generated or induced by popular media is closely linked to consumption. In the same way, the royal wedding in April 1959 between crown prince Akihito and his commoner princess Shōda Michiko was accompanied by a media event which in many ways induced, and indicated the beginning of a taish $\bar{u}$ tennosei, or 'Mass Emperor System', giving the audience the chance to imagine being 'in her white satin shoes' themselves. ${ }^{84}$ This story of aspiration will continue to be created by public demand in a broad spectrum of media, with or without the idols to star in them. In fact the trends in media long ago suggested that one day the audience would not only want to be 
in the shoes of their idols; their aspiration would eventually take them to the stage (and screen) masquerading as stars. As Featherstone puts it, the 'new petit bourgeois is a pretender', one whose 'search for expression and self expression, the fascination with identity and appearance, makes ... a natural consumer' ${ }^{85}$

The image of idols will eventually be democratised to the point that they become one of their own fans, and the fans will be elevated to the positions previously only occupied by stars. 'Audrey Hepburn', is thus merely an 'alias' in the rapidly virtualising media and physical landscape. 'The face of Audrey Hepburn' therefore inevitably will have many versions of embodiment. (See Figure 19: the face of Ōdorii.) Today, the stories in the media are designed for nothing but their own consumption - where the protagonists and the audience have become the same people. This, we call 'Reality Television'.

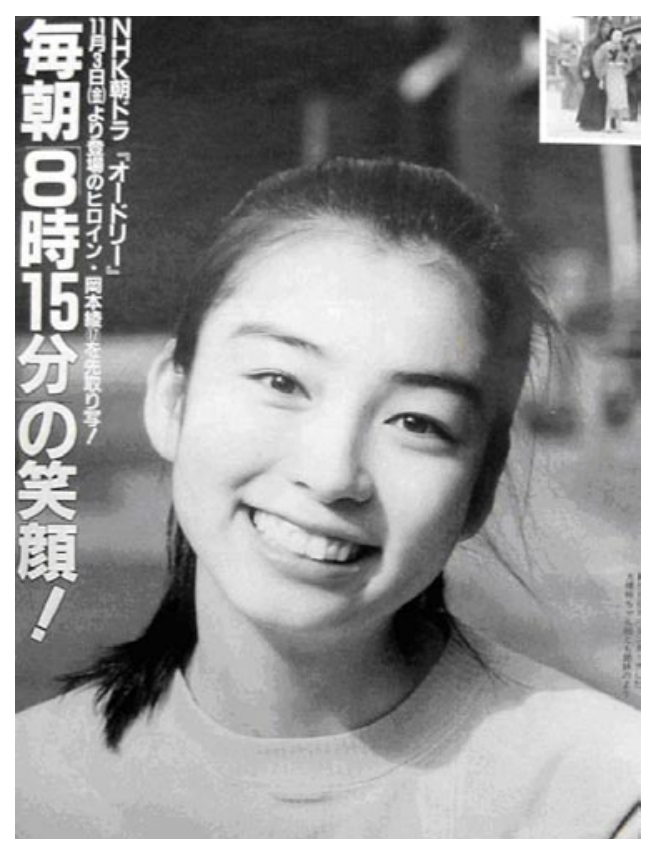

Figure 19: The face of Ōdorii

\section{ENDNOTES}

1 R. Barthes, 'The Face of Garbo', in Mythologies (Paris: Editions du Seuil), 1957, 56-57.

2 J.R. Clammer, Difference and Modernity: Social Theory and Contemporary Japanese Society (London: Kegan Paul International), 1995.

3 J.J. Tobin, ed. Re-Made in Japan: Everyday Life and Consumer Taste in a Changing Society (Connecticut: Yale University Press), 1992.

4 M. Ivy, 'Tradition and Difference in the Japanese Mass Media', Public Culture, Vol.1, No. 21, 29; See also, M. Ivy, Discourses of the Vanishing: Modernity, Phantasm and Japan (Chicago: University of Chicago Press), 1995.

5 See respectively, S. Lash, Sociology of Postmodernism (London: Routledge), 1990, J.Urry, The Tourist Gaze: Leisure and Travel in Contemporary Societies (London: Sage), 1990, J. Baudrillard, The Revenge of the Crystal: Selected Writings on the Modern Object and its Destiny, 1968-1983, ed. and trans. Paul Foss and Julian Pefanis (Leichardt: Pluto Press), 1990, W. Benjamin, 'The Work of Art in the age of Mechanical Reproduction', Illuminations, ed. Hannah Arendt (Glasgow: Fontana), 1973.

6 W. Benjamin, 221.

7 W. Benjamin, 1973, 221.

8 W. Benjamin, 1973, 221.

9 Urry, 1990, 85.

10 A. Appadurai, The Social Life of Things: Commodities in a Cultural Perspective (Cambridge: Cambridge University Press), 1986, 7.

11 Baudrillard, 66. 
12 R. Dyer, Stars (London: BFI Publishing), 1979.

13 J. Stacey, 'Feminine Fascinations: Forms of Identification in StarAudience Relations', in Christine Gledhill, ed. Stardom: Industry of Desire (London: Routledge), 1991.

14 Shūkan Shinchō 週刊新潮 Nihonjin wa naze Hepburn ga suki na no ka 日 本人はなぜヘップバーンが好き なのか. February 4, 1993, 38.

15 Stacey, 133-141.

16 All Yomimono オール読物, ‘Personality Spot: Audrey Hepburn' 人物スポッ ト：オードリー・ヘップバー, April 1954, 297. Thanks to David Kelly for translation of this paragraph.

17 Dime, "Audrey de manabu eikaiwa" made tōjō: A. Hepburn wa naze joseitachi no risō na no ka? 「オードリーで学ぶ英会話」ま で登場 A・ヘップバーンはなぜ女性た ちの理想なのか?, 3 December, 1992, 115.

18 Stacey, 154.

19 More, 'Anata wa Hepburn type? Soretomo Monroe type?' あなたはへ プバーン・タイブ?それともモン ロー・タイプ? , May, 1995, 17.

20 Josei Jishin, 'Audrey Hepburn vs. Julia Roberts' - dotchi ga kawaii オードリ ー・ヘップバーンV Vs. ジュリア・ ロバーツ どっちがかわいい. Josei Jishin, 16 April, 1991, 94-7.

21 All Yomimono, 1954.

22 W.D. Wolff, 'Kyoto date - Virtual Idol: A Retrospective View', 1997, http:/ / www.wdirewolff.com/ jkyoki.htm, downloaded 2003.

23 See Dime, 1992, All Yomimono, 1954.

24 C. Herzog and J. Baines, '"Puffed Sleeves Before Tea-Time": Joan Crawford,
Adrian and Women Audiences', in Stardom: Industry of Desire, ed. Christine Gledhill (London: Routledge), 1991, 74-91; Stacey 1991, 133, 141

25 Jinbutsu Hyōron 1971, 321; Non. no 1990, 111-117; More 1996, 332-3; With 1999, 74-79.

26 Shūkan Uriyomi 週刊売讀, Kijo mo watashi mo Hepburn - Tokyo musume no hairstyle o bunseki suru 貴女も私もへ ップバーンー東京娘のへアースタイ ルを分析する, 16 May, 1954, 3, 14.

27 See Gaines 1991.

28 Stacey, 1991.

29 Nakatani Akihiro 中谷彰宏, Audrey wa 23-sai de shinda オードリーは 23 歳で死んだ. Shūkan Post 週刊 ポスト 12 February, 1993, 221.

30 Iwabuchi Koichi has written extensively on the subject of Japanese cultural 'transnationalism' in Asia. Iwabuchi identifies 'cultural proximity' to Asia and the 'odourless-ness' as some of the main reasons for the acceptance of Japanese popular cultural products in many East Asian countries. Whether or not 'Japan' can be seen as a unified political entity in relation to the dominance of Japanese pop in Asian market places, I think the idea of 'odourless culture' gives a fitting description in the context of a highly networked global media landscape and the constant interflow of popular culture. See K. Iwabuchi, 1999, Returning to Asia-Japan in the cultural dynamics of globalisation, localisation and Asianisation. Ph.D. thesis, The School of Cultural Histories and Futures, (Sydney: University of Western Sydney); Iwabuchi, 2001, Becoming 'Culturally Proximate': the A/scent of Japanese Idol Dramas in Taiwan, in ed. Brian Moeran, Asian Media Productions, 54-74 (Richmond, Surrey: Curzon); Iwabuchi, Recentering Globalization: Popular Culture and Japanese Transnationalism (Durham: Duke University Press), 2002. 
31 In fact Hollywood has recently explored the impossible death of a popular virtual idol in a film titled S1MøNE (read 'Simone'; Dir. Andrew Niccol, 2002). The film has concluded that it is not easy to kill a computer image by simple erasure of data. The tired creator of Simone, played by Al Pacino, decides to ' $k$ ill' the virtual idol by a computer virus and dumping all 'her' computer data in the sea, only to face massive protests by her fans after announcing her death. In the end, not untypical of a Hollywood film, the data is saved by the creator's daughter, the virtual idol revives and this time lives happily ever after. Hollywood, of course, is not the inventor of this idea of the virtual idol. William Gibson has, in his novel Idoru (1996), written a technological prophecylike story, describing the realness of a virtual idol with both entertaining novelty and profound understanding of the 'soul' in the digital form.

32 Of course the idol used for Kirin's Afternoon Tea changes according the most current trend. A couple of idols have been on the Afternoon Tea commercials since they discontinued the Audrey Hepburn series.

33 See their homepage: http:/ / www.horipro.co.jp/htm

34 The use of the word 'talent' (tarento) in Japanese has little in common with the English term - it refers to entertainers (of no particular specialisation) in showbiz. The term is all-inclusive - a sportsman-turned-variety show guest is a 'talent'; a model-turned-drama actress occasionally giving opinions on a cooking show is also a 'talent'.

35 See his homepage: http://www. wdirewolff.com/jkyoko.htm

36 As a market phenomenon, Date Kyoko faded quickly after her 1996 debut, but seven years later in 2004, she continues to live in websites recounting her story in considerable detail. See for example: http:/ / members.tripod. com/ chinyankeat/dk96.htm

37 R. Kadrey, 'Importing a Virtual Star, Wired Vol. 6, No. 4, 1998, 60.

38 Y. Iida, 'Between the Technique of Living in an Endless Routine and the Madness of Absolute Degree Zero: Japanese Identity and the Crisis of Modernity in the 1990s', Positions, Vol. 8, No. 2, 2000, 429.

39 For detail of Fei Fei and e-frontier's other 'digital beauties' see their homepage: http://www.e-frontier. co.jp/digitalbeauty/feifei/index.html

40 Kanimiso Henshūkyoku, Fei Fei 3D Data Collection Official Book, 2000.

41 Samsung 23 May 2002. See: http:/ / www.samsung.co.jp/PressCenter/ Japan/020523_1.html; (e-frontier 1999).

42 Directed by Hironobu Sakaguchi and Moto Sakakibara.

43 See K. Bowen, 'We're not in Kansas Anymore', in http:/ / www.hollywood. com/celebs/features/feature/468436, 2001, downloaded 2004.

44 Bowen 2001.

45 Iida 2000, 428.

46 Iida 2000, 429.

47 Difficult, but not impossible - there are many computer games starring the digital version of their analogue counterparts in the physical world. The Taiwanese Japanese actor Kaneshiro Takeshi 金城武, for example, has an alias starring in the computer game called Oni musha 鬼武者. Today, the practice of making computer games paralleling blockbuster movies is common; the 007 computer game and more recently the game released with the Matrix are examples. The reverse can also be true - Final Fantasy, the 
movie, was based on the long running computer game of the same title.

48 Shūkan Heibon 週刊平凡, Hepburn ga Nihon no CM nanto, hitokoe dake de $¥ 50,000,000$ ヘップバーン が日本のCMなんと、ひと声だけで 5000万円, 22 April, 1971, 160.

49 The 1971 May conversion rate from Yen into US\$ was 357.41 (Exchange Rate Service, Sauder School of Business, University of British Columbia).

50 P.J. Asquith and A. Kalland, ed. Japanese Images of Nature: Cultural Perspectives (Richmond, Surry: Curzon Press), 1997.

51 Josei Jishin女性自身, (gravure) Konshū no photo digest: Audrey Hepburn ga 10-nen buri ni Nihon no CM ni kao o miseruグラビア 今週のフォトダイ ジェスト ; オートリ・ヘップバーン が 10 年ぶりに日本のCMに顔をみせ る, 18 March, 1982, inside back cover.

$52 \mathrm{CM}$ Connection, Hepburn appeared in a commercial for House Foods Co. (ハ ウス食品工業), http:/ / www.geocities. co.jp/hollywood/7269 / cinema06_ 01.html, downloaded 12 March 2003.

53 Hayamizu Yukiko 速水由起子, 1994, Joyū no keizai kōka: business no sekai de mo Hepburn ninki 女優の経済効 果 ビジネスの世界でもへップバ ーン人気. Aera, 7 November, 38.

54 Okamura Ryō 岡村良,1993, (gravure) Tokubetsu album Nihon de ichiban aisareta Hollywood joyū eien no heroine Audrey Hepburn グラビア 特別アルバム 日 本でいちばん愛されたハリウッド女 優 永遠のヒロイン オードリー・ ヘップバーン', Josei Seven 女性セブン, 1 January: 251, 258; Hayamizu 1994.

55 Dime 1992.

56 Shūkan Playboy 週刊プレイボーイ, Ojisan \& obasan no 'sekaiteki idol' wa donna hito? Audrey Hepburn tsuito no tame no kiso chishiki オジサン\&オバサ ンの「世界的アイドル」はどんな人?
オードリ・ヘップバーン追悼の為の

基礎知識, 9 February, 1993, 236, 237.

57 Shūkan Shinchō 週刊新潮1993 Nihonjin wa naze Hepburn ga suki na no ka 日本人はな ぜヘップバーンが好きなのか. February 4, 1993, 32-33; Non.no. 1993. Memorial travel Hepburn ga aishita machi Suisu • Rozannuメモリアル・トラベルヘップ バーンが愛した街スイス・ローザンヌ， 166-179; Non.no, 5 August, 166, 179.

58 More, 1996, Beauty Special, Kyōi no eyeline-teku de Audrey-gao ni naru / Audrey no eye-make no himitsu 驚異のアイライン テクでオードリー顔になる|オードリ 一のアイメイクの秘密. More, January, 332, 333; More, 1998, Ima sugu mane shitai. Cinema wa sense no hōko / Watashi no nichijō-gi. O-tehon wa ano eiga no ano joyū Audrey Hepburn 今すぐ真似したい。ジ マはセンスの宝庫|わたしの日常着。お 手本はあの映画のあの女優 オードリー ・ヘップバーン. More, March, 172, 173;

With, Audrey Hepburn, anata no fashion ga ima de mo o-tehon desu オードリー・ヘ ップバーン あなたのファッションが今 でもお手本です, September, 1999, 74, 79.

59 Non.No, Audrey Hepburn ima nao “aisareru riyü" オードリ・ヘップ バーン今なお「愛される理由」， 5 December, 1990, 111, 117.

60 Roman Holiday had some 10 Oscar nominations. Audrey Hepburn won Best Actress for her performance in the film. www.oscar.org/events/ roman_holiday/index.html

61 K. Tanaka, 'Intelligent Elegance:

Women in Japanese Advertising', in Unwrapping Japan: Society and Culture in Anthropological Perspective, ed. Eyal Ben-Ari, Brian Moeran \& James Valentine (Manchester: Manchester University Press) 1990, 78-96.

62 The consumption of European brandname shoes, for example, is nothing short of extraordinary. According to a detailed survey done on consumption of brand-name shoes by Ide Yukie (1998), on average, working women in their 
20s, have about 6 brand-name shoes, buy about 2 pairs a year, and more than $40 \%$ of those surveyed spent between $¥ 40,000-70,000$ (US\$1 = $¥ 110$ roughly) on each pair. This means that on average each Japanese working woman in their 20 s would own between $¥ 120,000$ and $¥ 210,000$ worth of shoes at any one time, and spend around $¥ 80,000$ to $¥ 140,000$ a year on shoes. The most soughtafter brands are respectively Chanel, Louis Vuitton, Prada, Ferragammo, and Fendi. All of them are European.

63 M.R. Creighton, 'The Depāto:

Merchandising the West While Selling Japaneseness', in Re-made in Japan: Everyday Life and Consumer Taste in a Changing Society, ed. Joseph J. Tobin (Connecticut: Yale University Press), 1992, 42-57; M.R. Creighton, 'Something More: Japanese Department Stores' Marketing of "A Meaningful Human Life"', in Asian Department Stores, ed. Kerrie L. MacPherson (Richmond, Surrey: Curzon), 1998, 206-230; T. Havens, Architects of Affluence: The Tsutsumi Family and the Seibu-Saison Enterprises in Twentieth-Century Japan (Cambridge, Mass.: Council on East Asian Studies, Harvard University), 1994; C. Ueno, 'Seibu Department Store and Image Marketing: Japanese Consumerism in the Postwar Period', in Asian Department Stores, 177-205.

64 The song is a confession by a woman who falls in love with a man just a day before getting married to another. She felt the 'Audrey Hepburn Complex', apparently describing a sentiment or/ and paranoia of being watched, and felt 'head aches and dizziness, etc.' rain.org (2001). http:/ / www.rain.org/ mills/ pizzlyrics/pizzicatomania.html.

65 F. Jameson, 'Nostalgia for the Present', South Atlantic Quarterly, Vol., 88, No. 2, 1989, 517-537.

66 Appadurai 1996

67 Hanamori Yasuharu 花森安治, 'Hepburn o kaibō suru ヘップバーンを解剖

する. Maru丸, July 1954, 66, 72.

68 Shūkan Uriyomi 週刊売讀, Kijo mo watashi mo Hepburn - Tokyo musume no hairstyle o bunseki suru 貴女も私もへ ップバーンー東京娘のへアースタイ ルを分析する, 16 May, 1954, 3, 14.

69 Hanamori 1954.

70 The original text was: といっても、オー ドリーを日本の部屋にきちんと坐らせた ら、あの美しさは死んでしまうだろ, 69.

71 Yoshimoto Mitsuhiro, 'Real Virtuality', in Global/Local: Cultural Production and the Transnational Imaginary, ed. Rob Wilson \& Wimal Dissanayake (Durham: Duke University Press), 1996, 111.

72 Kirin is not the first to play with the idea of history; nor is Hepburn the first ghost to come alive. Films such as Blade Runner, and the anime Ghost in the Shell, and more recently the film Matrix all used nostalgic and exotic visual presentations to render the future. The contemporary use of the 'past' to express the idea of the 'future' deserves a thorough analysis in terms of the meaning of history in the digital era on a different occasion.

73 NHK (2000). http://www.nhk.or.jp/pr/ bangumi/asadra/story/001.html

74 M. Ivy, 1995.

75 The exhibition started in Tokyo's fashion centre Shibuya (22 May - 4 July 2004) causing long queues of her fans waiting outside 'The Museum' in Bunkamura. 'Timeless Audrey' tours the nation until 11 February 2005 and ends in Takashimaya department store in Namba, Osaka.

76 Yoshimoto, Mitsuhiro, 'The Postmodern and Mass Images in Japan', Public Culture, Vol. 1, No. 2, 1989, 10.

77 Yoshimoto 1989, 13. 
78 M.Y. Brannen, 'Bwana Mickey: Constructing Cultural Consumption at Tokyo Disneyland', in Re-made in Japan: Everyday Life and Consumer Taste in a Changing Society, ed. Joseph J. Tobin (Connecticut: Yale University Press), 1992, 216-234.

79 Yoshimi, Shunya, 'The Politics of Disneyland - Tokyo Disneyland and Commercial Culture in Contemporary Japan', Conference Paper, Mexico, 1993.

801989.

81 In the case of Mickey Mouse, it is a matter of its licensing agreement that came with Tokyo Disneyland (TDL). Financially Mickey Mouse is no more 'American' than TDL itself and no less Japanese than the approximately 90 percent of all its sales and profits owned by the Japanese Oriental Land Ltd. See J. Findlay, Magic Lands: Western Cityscapes and American Culture After 1940 (Berkeley: University of California Press), 1992, and J.Wasko, Understanding Disney: The Manufacture of Fantasy

(Cambridge: Polity Press), 2001.

82 J.B. Twitchell, Living It Up: Our Love Affair with Luxury (New York: Columbia University Press), 2002, 154-9. See also Twitchell, Adcult USA: The Triumph of Advertising in American Culture (New York: Columbia University Press), 1996.

83 O.E. Klapp, Collective Search for Identity (New York: Holt Rinehart and Winston), 1969, 80, 218.

84 S. Partner, Assembled in Japan: Electrical Goods and the Making of the Japanese Consumer (Berkeley: University of California Press), 1999, 173-75. According to Partner, the extensive media coverage on the commoner princess, Michiko (as she is familiarly known by the Japanese) also included detailed description of the so called Michi-style fashion: clothing sported by Shōda Michiko, with instructions on where to buy them, and how much they cost.
85 M. Featherstone, Consumer Culture and Postmodernism (London: Sage), 1991, 90. 